\title{
Land use, spatial heterogeneity of organic matter, granulometric fractions and metal complexation in reservoir sediments
}

\author{
Uso e ocupação do solo, heterogeneidade espacial de matéria orgânica, fraçóes \\ granulométricas e complexação de metais em sedimentos de reservatório
}

\section{Thaís Fabiane Gomes Martins ${ }^{1}$ (D), Karen de Souza Ferreira ${ }^{1}$ (D), Bárbara Rani-Borges ${ }^{1}$ (D),}

Ivan Edward Biamont-Rojas ${ }^{1}$ (D), Sheila Cardoso-Silva ${ }^{2,3}$ (D), Viviane Moschini-Carlos ${ }^{1}$ (D) and

$$
\text { Marcelo Luiz Martins Pompêo }{ }^{4 *} \text { (D) }
$$

\begin{abstract}
'Programa de Pós-graduação em Ciências Ambientais, Instituto de Ciência e Tecnologia, Universidade Estadual Paulista - UNESP, Campus de Sorocaba, Av. Três de Março, 511, Alto da Boa Vista, CEP 18087-180, Sorocaba, SP, Brasil

${ }^{2}$ Programa de Pós-graduação em Ecologia e Manejo de Recursos Naturais, Universidade Federal do Acre - UFAC, Rodovia BR 364, Km 04, CEP 69920-900, Rio Branco, AC, Brasil

${ }^{3}$ Universidade de São Paulo, Instituto de Oceanografia - IOUSP, Praça do Oceanográfico, 191, CEP 05508-120, São Paulo, SP, Brasil

${ }^{4}$ Laboratório de Limnologia, Departamento de Ecologia, Universidade de São Paulo, Instituto de Biologia - IB, Universidade de São Paulo - USP, Rua do Matão, Travessa 14, 321, Butantã, CEP 05508-090, São Paulo, SP, Brasil

*e-mail: mpompeo@ib.usp.br
\end{abstract}

Cite as: Martins, T.F.G. et al. Land use, spatial heterogeneity of organic matter, granulometric fractions and metal complexation in reservoir sediments. Acta Limnologica Brasiliensia, 2021, vol. 33, e23.

Abstract: Aim: This study aimed to evaluate land use, distribution of particle size fractions, organic matter $(\mathrm{OM})$ and perform a metal quantification liable to complexation in the Itupararanga Reservoir (São Paulo, Brazil). This aquatic ecosystem is used for water supply and energy generation and is constantly subjected to anthropogenic impacts that alter its physical and chemical characteristics. Methods: In a single campaign, samples of surface sediment $(10 \mathrm{~cm})$ were collected from nine sampling stations, in triplicate, along the reservoir. The collection was carried out with a "Lenz" type bottom sampler. The physicochemical variables, including the quantification of the metals copper, chromium, manganese, nickel, lead and zinc, were evaluated by basic descriptive statistics techniques combined with geostatistics and the use of remote sensing. Results: All along the reservoir the sediment is predominantly organic and water depth interfered directly in the OM concentration and particle size distribution. Therefore, heterogeneity was observed regarding OM contents, particle size fractions and metals, with the exception of chromium, and the three zones of the reservoir proved to be distinct from each other. The land use classification showed the real situation of the Environmental Protection Area (EPA) and the results indicate that the central portion is more subject to anthropic impacts, while the dam region has high levels of metals, probably originated from the activities in the reservoir's surroundings. Conclusions: The soil erosion in the reservoir's region shows the lack of efficiency in the Itupararanga EPA's management, being needed a strategic coordination among the municipalities to enhance its conservation.

Keywords: decomposition; complexing of metals; freshwater reservoir; sedimentation; water depth. 
Resumo: Objetivo: Este estudo teve como objetivo avaliar os usos do solo, a distribuição das fraçóes granulométricas, matéria orgânica $(\mathrm{MO})$ e metais propensos à complexação no Reservatório de Itupararanga (São Paulo, Brasil). Este ecossistema aquático é empregado para o abastecimento de água e na geração de energia e está submetido constantemente a impactos antrópicos que alteram suas características físicas e químicas. Métodos: Em campanha única, foram coletadas amostras de sedimento superficial $(10 \mathrm{~cm})$ de nove estações de amostragem, em triplicata, ao longo do reservatório. A coleta foi realizada com um amostrador de fundo tipo "Lenz". As variáveis físico-químicas, incluindo a quantificação dos metais cobre, cromo, manganês, níquel, chumbo e zinco, foram avaliadas por técnicas de estatística descritiva básica unidas a geoestatística e o uso de sensoriamento remoto. Resultados: Ao longo de todo o reservatório o sedimento é predominantemente orgânico e a profundidade interferiu diretamente na concentração de $\mathrm{MO}$ e na distribuição granulométrica. Portanto, foi observada heterogeneidade quanto aos teores de $\mathrm{MO}$, fraçóes granulométricas e metais, com exceção do cromo, e as três zonas do reservatório provaram-se distintas entre si. A classificação do uso e ocupação do solo mostrou a real situação da Área de Proteção Ambiental (APA) e os resultados indicam que a porçâo central está mais sujeita a impactos antrópicos, enquanto a regiáo da barragem apresenta altos níveis de metais provenientes de atividades do entorno do reservatório. Conclusóes: $\mathrm{O}$ elevado desgaste do solo na região demonstra que a gestáo da APA de Itupararanga é deficiente, sendo necessária a elaboração de uma coordenação estratégica entre os municípios para melhorar a conservação da área.

Palavras-chave: decomposição; complexação de metais; reservatório de água doce; sedimentação; uso do solo.

\section{Introduction}

Freshwater reservoirs are hydraulic units of high social, economic and environmental importance, as they are fundamental for the maintenance of the population served by their ecosystem services and the biological communities present there. Poor water and/or sediment quality can damage the dweller's health and the loss of local biodiversity (Abell et al., 2019). The guarantee of a safe and quality water distributed by these structures, whichever the final use is: public supply, irrigation, electricity generation, navigation, recreation or other, is an essential task (Silva et al., 2016), and must be carried out continuously and permanently.

Reservoirs function as information storage systems for events happening now and past within the watershed, partly under external influences (de Melo Gurgel et al., 2016; Henry, 1990). Within this scenario, sediments represent the integration among physical, chemical and biological processes in the aquatic environment in which it is located. Therefore, it is able to establish a safe connection to evaluate the environmental degradation of these units. Thus, the study of sediment is crucial when it aims to investigate the reservoir's environmental quality (Mizael et al., 2020; Pompêo et al., 2013).

A widely used indicator for sediment characterization is the organic matter (OM) assessment. OM present in sediments interferes with some water quality parameters, such as dissolved oxygen availability, transparency, nutrient load and phytoplankton temporal variability, for example. In the case of phytoplankton communities, high concentrations of OM are related to blooms, which can trigger a series of environmental events with serious consequences (Liu et al., 2021). Therefore, the study of phytoplankton as an indicator allows to attribute a direct relationship to a reservoirs chemical, ecological and environmental degradation (Atique \& An, 2020).

Sediments are composed of particles of very diverse characteristics that together determine and provide unique biogeochemical properties to each sediment (Von Eynatten et al., 2016). These properties are conditioning factors for the frequency and distribution of benthic organisms. Sediment grains smaller than $63 \triangle \mathrm{m}$ have a higher pollutant retention capacity, which makes granulometric and chemical composition studies to provide valuable data about the presence and destination of various contaminants and their consequences for the ecosystem (Pérez et al., 2020).

There are several pollutants in aquatic environments, among them a class that stands out is the metals. Metals present in reservoirs may have geogenic or anthropogenic origin, the latter being mainly caused by chemical fertilizers usage in the vicinity or due to irregular release of household and industrial waste (Bing et al., 2013). Since the persistence, bioaccumulation tendency and high toxicity of metals (Pavlović et al., 2016; Proshad et al., 2018), the research of these components is relevant in several aspects, besides being fundamental for ensuring environmental quality and promoting public health.

In this context, an innovative geostatistical approach was applied as a tool to assist in the management of drinking water supply reservoirs, 
through the correlation of the assessed parameters and data interpolation by kriging method, enabling predictions of the areas with greater disposition to the metal complexation and other pollutants. These data can certainly contribute decisively to the entire scientific community focused on studies related to the environment, water and sediment quality, through the description of a methodology capable of indicating the stations that need greater attention, besides demonstrating its potential to serve as an instrument to improve public environmental policies and to ensure public health.

Therefore, it has been chosen the Itupararanga subtropical reservoir (São Paulo, Brazil), due to its multiple uses, its regional, social, and economic relevance. Thus, the research's objective was to assess the land use, spatial heterogeneity of the granulometric and OM concentrations, as well as to explore areas with metal complexation potential in the Itupararanga reservoir. This approach assisted the study of probable influences in the land use degradation in the Environmental Protection Area (EPA) where the reservoir is inserted, in order to provide support to the local biota and/or human being risk analysis.

\section{Material and Methods}

\subsection{Study area}

The Itupararanga reservoir (Figure 1) is located in the Sorocaba river which belongs to Alto Sorocaba Basin, and this basin belongs to Médio
Tietê river. Created in 1913, the reservoir is formed by the Sorocabaçu, Sorocamirim and Una rivers, including the municipalities of Ibiúna, Piedade, São Roque, Mairinque, Alumínio, and Votorantim (Rosa et al., 2015). The reservoir has a drainage area of $936.5 \mathrm{~km}^{2}$ with a length of $26 \mathrm{~km}$ in the principal channel, a maximum flow of $39.13 \mathrm{~m}^{3} \mathrm{~s}^{-1}$ and a maximum volume of 286 million of $\mathrm{m}^{3}$ (Rosa et al., 2015). According to the Köppen classification, this region has a Cwb (Altitude subtropical) climate, with rainy summer and stivation peaks during winter, the mean annual precipitation is $1360 \mathrm{~mm}$ (Abreu \& Tonello, 2017).

When the Environmental Protection Area (EPA) of Itupararanga Reservoir (Brazil) was created, by State Law $n^{\circ} 10.100$, on December 1 1 altered by State Law 11.579, on December $2^{\text {nd }}$, 2003 (São Paulo, 2003), it was intended to protect the reservoir's surrounding area where are located some forest fragments and it is responsible for the majority presence of the local biodiversity (Beu et al., 2011). The Itupararanga EPA covers the whole area of Sorocaba river basin. However, areas next to the reservoir are being compromised due to illegal occupation and land use principally for agricultural activities as well as domestic and industrial sewage inflows, from the cities of Ibiúna, Vargem Grande Paulista and from Caucaia do Alto District in Cotia (Beu et al., 2011; Valente, 2011), this compromises the water quality and increases its degradation.

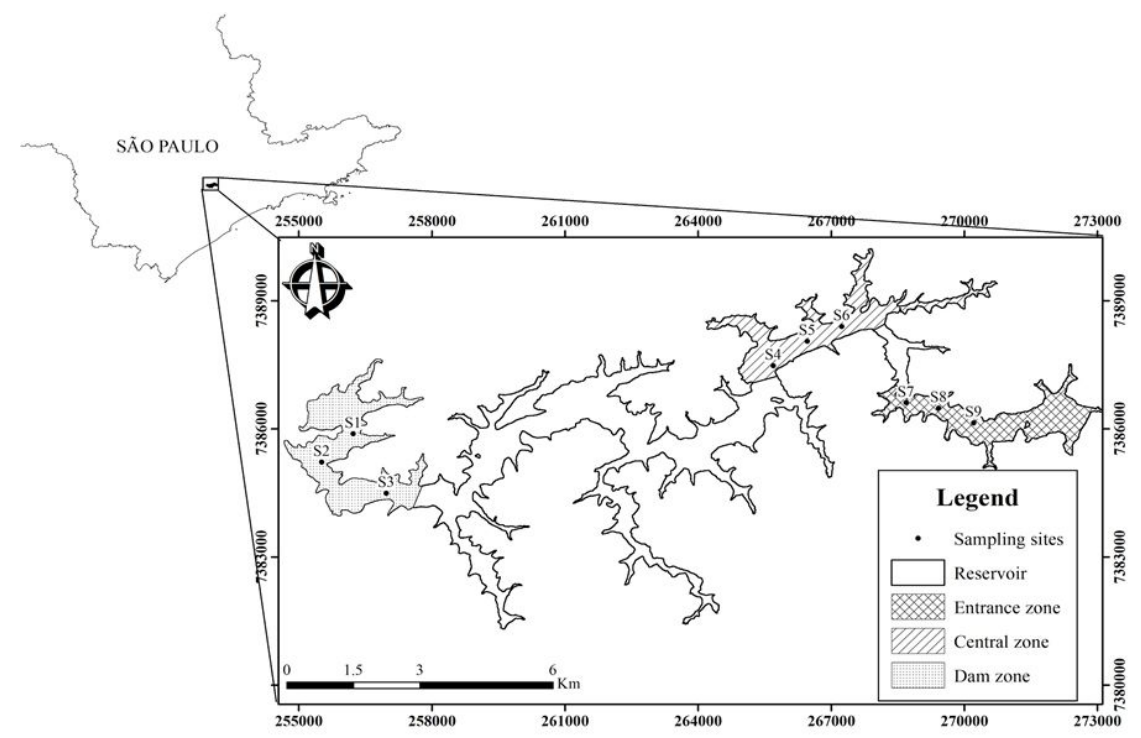

Figure 1. Itupararanga reservoir location and sampling stations (S1-S9). The first image represents the map of the state of Sáo Paulo, including the city of Sorocaba, where the reservoir is located. The entire length of the Itupararanga reservoir is highlighted, indicating the stations where the sediment collection was performed. 


\subsection{Sampling design}

Surficial sediment samples were collected in three compartments distributed along the reservoir in March 2019. The sampling stations location were defined based on previous results carried out in the same region (Rosa et al., 2015; Taniwaki et al., 2013), where the results showed that these stations had higher rates of environmental degradation caused by anthropogenic activities.

In each compartment, the sampling procedure was done in triplicate (making a total of 27 samples), where two compartments were located in the higher part of the reservoir and the last one close to the dam (Table 1). The sampling sites were georeferenced with a GPS (Global Positioning System) Garmin Montana 600 (Datum WGS-84) and water depth was measured with a manual probe PLASTIMO Echotest II.

The sediment samples were collected using a sampler type "Lenz", a modified version of EkmanBirge (Leal et al., 2018), of $5000 \mathrm{~mL}$. This sediment was stored in plastic flasks of $2000 \mathrm{~mL}$ and conditioned in thermic bags with artificial ice in dark conditions kept at $4{ }^{\circ} \mathrm{C}$ until the analysis process (ANA, 2011).

\subsection{Land use classification}

Landsat 8 - OLI (Operational Land Imager) Imagery has been obtained from the USGS database (USGS, 2021). The scenes under the orbit $\left(219 / 076\right.$, August $\left.17^{\text {th }}, 2019\right)$ were obtained. These images have $30 \mathrm{~m}$ of spatial resolution. This land use classification in ArcGIS 10.4 software, performed throughout the Supervised classification, the Maximum Likelihood Classification method, observing the following categories: Forest, Water, Urban, Exposed soil and Grassland.

\subsection{Organic matter determination}

To determine the organic matter (OM) contents, $200 \mathrm{~g}$ of sediment were dried in an oven

Table 1. Sampling stations (S) location and depth (m) at the Itupararanga reservoir (São Paulo State, Brazil).

\begin{tabular}{cccc}
\hline \multirow{2}{*}{$\begin{array}{c}\text { Sampling } \\
\text { stations }\end{array}$} & \multicolumn{3}{c}{ Sites characteristics } \\
\cline { 2 - 4 } & Latitude S & Longitude W & Depth $(\mathbf{m})$ \\
\hline S1 & $23^{\circ} 37^{\prime} 09^{\prime \prime}$ & $47^{\circ} 23^{\prime} 21^{\prime \prime}$ & 18.1 \\
S2 & $23^{\circ} 37^{\prime} 30^{\prime \prime}$ & $47^{\circ} 23^{\prime} 46^{\prime \prime}$ & 17.8 \\
S3 & $23^{\circ} 37^{\prime} 55^{\prime \prime}$ & $47^{\circ} 22^{\prime} 55^{\prime \prime}$ & 17.5 \\
S4 & $23^{\circ} 36^{\prime} 22^{\prime \prime}$ & $47^{\circ} 17^{\prime} 46^{\prime \prime}$ & 8.7 \\
S5 & $23^{\circ} 36^{\prime} 04^{\prime \prime}$ & $47^{\circ} 17^{\prime} 19^{\prime \prime}$ & 8.4 \\
S6 & $23^{\circ} 35^{\prime} 53^{\prime \prime}$ & $47^{\circ} 16^{\prime} 51^{\prime \prime}$ & 8.7 \\
S7 & $23^{\circ} 36^{\prime} 52^{\prime \prime}$ & $47^{\circ} 16^{\prime} 01^{\prime \prime}$ & 6.9 \\
S8 & $23^{\circ} 36^{\prime} 56^{\prime \prime}$ & $47^{\circ} 15^{\prime} 35^{\prime \prime}$ & 6.8 \\
S9 & $23^{\circ} 37^{\prime} 08^{\prime \prime}$ & $47^{\circ} 15^{\prime} 08^{\prime \prime}$ & 5.4 \\
\hline
\end{tabular}

at $60{ }^{\circ} \mathrm{C}$ for 6 days. Later, the dried samples were grounded in a glass mortar. Then, these samples were homogenized in a $2 \mathrm{~mm}$ sieve and stored. The resulting samples were put in washed, dried, and identified crucibles, passed through a muffle at $550{ }^{\circ} \mathrm{C}$, for $4 \mathrm{~h}$ (Heiri et al., 2001). These crucibles were cooled in a pressured desiccator for two hours and weighted (0.1 mg accuracy; model Mettler Toledo AB 204-S, 2004) to add $0.5 \mathrm{~g}$ of dried sediment. Later, those crucibles returned to the muffle for $4 \mathrm{~h}$, at $550{ }^{\circ} \mathrm{C}$. After that, the crucibles were cooled once again in a pressured desiccator for a final weighing (crucible and sample). From these results we calculated the OM, expressed as percentage, which is the difference between the first and second weighing, considering the burned material represents the OM.

\subsection{Granulometric analysis}

This analysis was performed according to the methodology proposed by Suguio (1973), with adaptations. Initially, we did the OM digestion of $10 \mathrm{~g}$ of dried sediment aliquot, with a hydrogen peroxide solution $\left(\mathrm{H}_{2} \mathrm{O}_{2} 10 \%\right.$, v/v) at $80^{\circ} \mathrm{C}$ for 16 to $40 \mathrm{~h}$, until the $\mathrm{OM}$ was broken down completely. Then, the samples were distributed individually in trays and put into the stove at $105{ }^{\circ} \mathrm{C}$ until they were completely dried. Finally, the samples were weighted to determine the granulometric composition and, these fractions passed through various sieves $(2.0,1.0,0.5,0.25$, and $0.12 \mathrm{~mm})$ for their classification according to its size in coarse sand, thin sand, fraction silt and clay (Carmo \& Silva, 2012).

\subsection{Metal concentrations}

Copper $(\mathrm{Cu})$, Chromium (Cr), Manganese $(\mathrm{Mn})$, Nickel $(\mathrm{Ni})$, Lead $(\mathrm{Pb})$, and Zinc $(\mathrm{Zn})$ have been chosen due to their toxic potential (Consalter et al., 2019; Mizael et al., 2020; Schaumlöffel, 2012; Da Paz Schiller et al., 2019), complexation capacity with the $\mathrm{OM}$ and thin fraction of the sediment (Föstner \& Salomons, 1980). Besides that, these metals are widely used in agricultural, industrial, and mining activities (Bernardi et al., 2020) around the studied region, which can lead to higher concentrations in the reservoir.

The metal concentration assessment was carried out following the United States Environmental Protection Agency (U.S. EPA) 3050-B method (U.S. EPA, 2001). We added $10 \mathrm{~mL}$ of nitric acid $\left(\mathrm{HNO}_{3}\right)$ (P.A.) in $1 \mathrm{~g}$ of dried sediment sample, then 
heated at $95{ }^{\circ} \mathrm{C}$ for $120 \mathrm{~min}$ in a digester block. After that, we added $5 \mathrm{~mL}$ of hydrogen peroxide $\left(\mathrm{H}_{2} \mathrm{O}_{2}\right)$ at $30 \%$, keeping the solution warm during the same period of time. Finally, we pour $10 \mathrm{~mL}$ of chloric acid $(\mathrm{HCl})$ and heated during $15 \mathrm{~min}$. When this heating process finished the resulting solution was filtered, in a glass funnel, using a Whatman ${ }^{\mathrm{TM}}$ 541 filter of $150 \mathrm{~mm}$, and completed to $100 \mathrm{~mL}$. The metal assessment was performed by inductively coupled plasma atomic emission spectrometry (ICP-AES), using an Agilent Series 720 instrument and data was expressed as $\mathrm{mg} \mathrm{kg}^{-1}$ dry mass.

\subsection{Statistical analysis}

We calculated the variation coefficient and Pearson correlation coefficients $(r)(\mathrm{p}=<0.05)$, to verify the relationship degree among the variables. Data was analyzed using PAST $2.17^{\circ}$ (Hammer et al., 2001).

The OM spatial layout in the reservoir was created using a deterministic interpolation algorithm, the Inverse Distance Weighting (IDW). This method uses values in the proximity to sample stations to predict the data pattern, assuming that zones close to our sites are more similar than distant zones. Therefore, values close to our sampling stations will have more influence in this interpolation process than the distant ones (Shepard, 1968). The Equation 1 was used to calculate the unknown values.

$$
\hat{Z}_{j}=\frac{\sum_{i=1}^{n} \frac{z_{i}}{d_{i j}^{2}}}{\sum_{i=1}^{n} \frac{1}{d_{i j}^{2}}}
$$

where: $\hat{Z} j$ is the estimated value for the sampled station; $d$ is the distance of a certain point; $z$ is the value of $z$ in a known point $i ; n$ is the number of points included in the prediction; and $i$ is the number of the point that will be considered.

The most used weighting is the inverse distance of the Euclidean weighting from a point in the grid to the considered sample (Equation 2):

$\sqrt[d_{i j}]{\left(x_{i}-x_{j}\right)^{2}+\left(y_{i}-y_{j}\right)^{2}}$

Both the data processing and map construction was performed in a Geographic Information System (GIS) environment using the QGIS 3.10.5 (A
Coruña) software. The relationship among the sampling sites and the distribution of metals, grain size and OM were verified through a Principal Component Analysis (PCA) using PAST 2.17 (An et al., 2015). The data were logarithmized using PAST $2.17^{\circ}$, aiming to minimize the differences among variables with various units.

\section{Results and Discussion}

\subsection{Analysis of land use in the Environmental Protection Area (EPA) of Itupararanga Reservoir (Brazil)}

Figure 2 shows the land use classification map in Itupararanga EPA. The results show that the EPA is a big area with high forest coverage $(42.7 \%)$, followed by grasslands (26.65\%) and exposed soil $(4.76 \%)$. The predominant vegetation is the ombrophilous dense forest (Bernardi et al., 2020). However, land use indicators demonstrate that this region is gradually losing natural areas within the EPA, being substituted by small secondary forest patches (Almeida et al., 2011; Bernardi et al., 2020). It is observed a disorganized urban area occupation $(23.98 \%)$ summed to an increased population density close to water masses $(2.14 \%)$.

The spectral response of Landsat 8-OLI imagery was limited to categorize the inlet rivers to the reservoir, due to the spatial resolution which was bigger than the rivers in the region. Some interference can happen when applying the Maximum Likelihood algorithm because of similar spectral responses, mainly in areas with high inorganic and chlorophyll concentrations (De Castro et al., 2017). The environmental pressure experienced in the EPA region affect directly in the reservoir's water quality, that currently is the main source of drinking water in the region, supplying almost one million dwellers among the Sorocaba river high course and middle course of Tietê river (Bernardi et al., 2020; Taniwaki et al., 2011).

\subsection{Spatial distribution of organic matter in sediments}

Once the spatial modeling was performed, shown on the map in Figure 3, it was possible to quantify the OM contents along the entire reservoir. The data showed a decreasing gradient over the reservoir, with the highest levels of OM found near the entrance to the reservoir. In general, OM concentrations decreased in the upstream direction, except for the transition zone, which presented levels between $16.67 \%$ and $18.11 \%$, with a positive correlation 


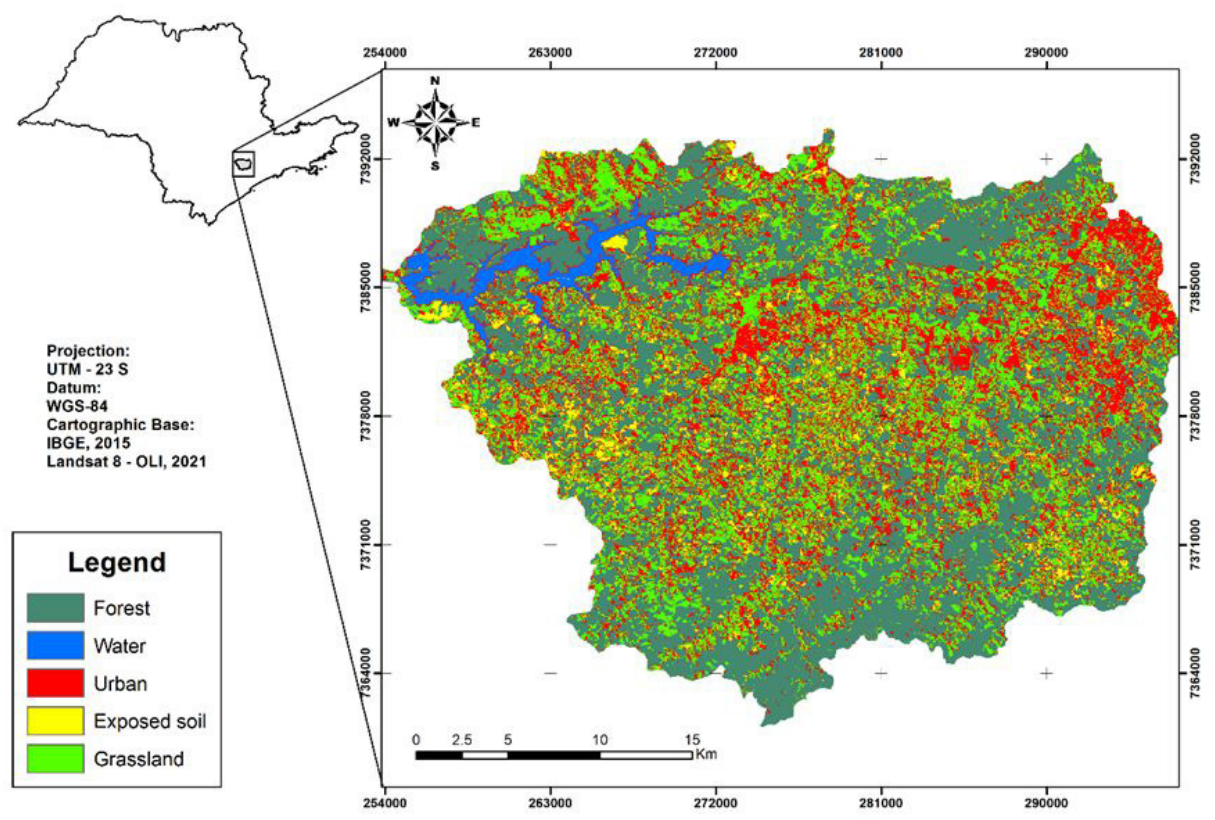

Figure 2. Land use classification map in the Environmental Protection Area (EPA) of Itupararanga. The land use classification shapes were defined proportionally throughout the imagery obtained by remote sensing.

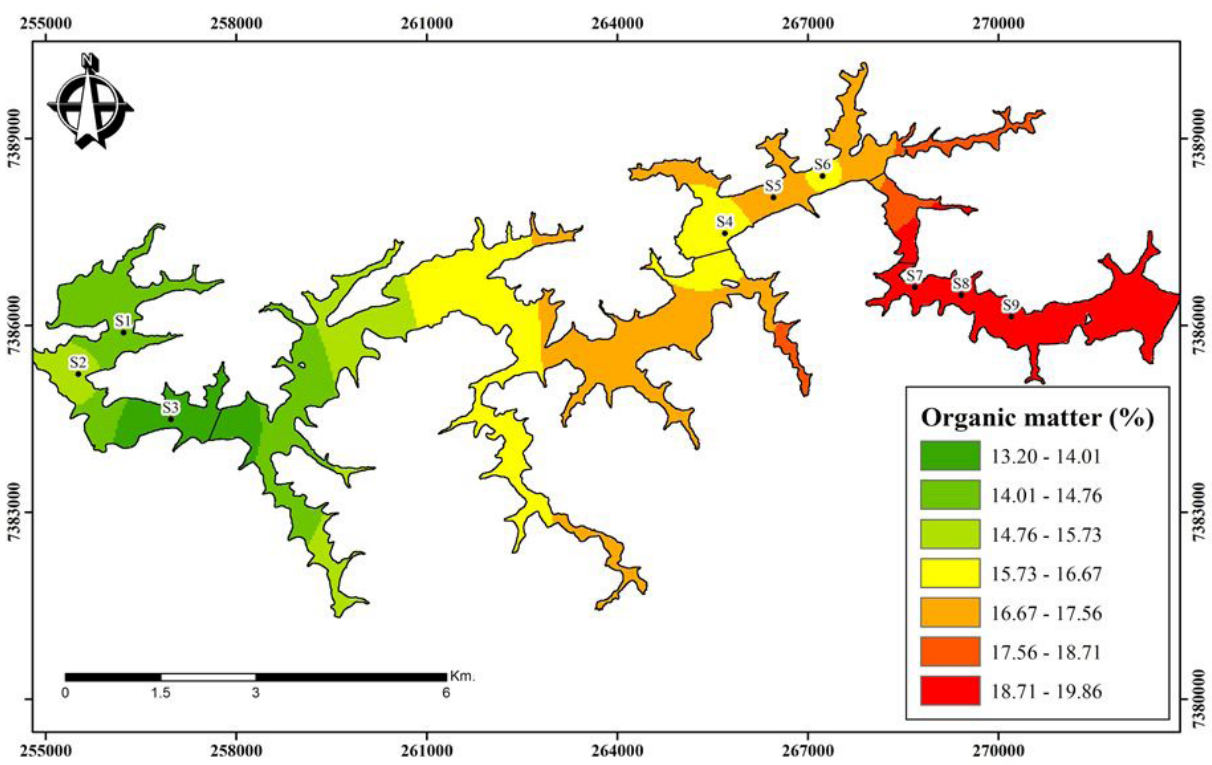

Figure 3. Map of the organic matter $(\mathrm{OM}, \%)$ distribution. The colors of the map represent the percentage of organic matter found along the reservoir, according to the organic matter amount assessed. The areas where no sampling collection occurred were filled according to the interpolation of data applied through geostatistics.

between the sampling stations and the OM contents $(\mathrm{r}=0.88)$. This area has intense agricultural activity along the reservoir margins, which may be an indicator of $\mathrm{OM}$ concentrations in this area. In the study presented by Taniwaki et al. (2013), the authors found high concentrations of OM in the same zone, indicating that the area has been experiencing intense occupation for several years.

In the present work, the composition of the analyzed sediment is considered organic (Esteves, 2011), 
presenting all stations with levels above $10 \%$. This may be associated with the contribution of allochthonous organic material and possible releases of sewage from the surrounding cities (Frascareli et al., 2015). These results disagree from those found by Silva (2012), in a study carried out in 2011, in places close to the same stations of this work, where the reservoir had an average of $6.28 \% \mathrm{OM}$, being the lowest content presented $1.68 \%$ and the highest $14.27 \%$. Such a difference in the results can be attributed to the period of collection of the study, carried out in the winter and in this study carried out in the summer and by the intensification of the reservoir eutrophication process over the years. For Esteves (2011), the increase in temperature in water bodies leads to the intensification of decomposition of $\mathrm{OM}$, since there is a transfer of heat from the surface to the hypolimnion, driving the death of aquatic organisms and, consequently, increasing the amount of OM. From data released by the Environmental Company of the State of São Paulo (CETESB, 2019) for the Trophic State Index (TSI), an increase in the trophic state was observed between the year of study by Silva (2012) until 2018, the latest data available until now. Between the years 2010 to 2018, the TSI evolved negatively from ultraoligotrophic to mesotrophic.

The upstream part of the reservoir showed higher percentages of OM in relation to the dam area, a result that is corroborated by Frascareli et al. (2015). These authors, for that same portion of the reservoir, determined the trophic state of the reservoir entrance zone as hypereutrophic and the dam varying between mesotrophic and eutrophic. The study by Melo et al. (2019) indicated the reservoir entrance zone as supereutrophic and eutrophic and the dam zone was characterized as mesotrophic and oligotrophic. Still in the same study, the authors attributed the results to the land use in the regions surrounding the reservoir. Since the dam area is predominantly focused on agricultural and forestry activities, the reservoir entrance is composed of pastures, with high levels of nitrogen compounds, including ammonium $\left(\mathrm{NH}_{4}^{+}\right)$ and nitrate $\left(\mathrm{NO}_{3}{ }^{-}\right)$. These chemical species indicate that untreated industrial and domestic effluents are discharged, captured by the Sorocabuçu, Sorocamirim and Una rivers. These results were corroborated by Pedrazzi et al. (2012), who also observed an OM contribution to Sorocaba River, a highly impacted ecosystem by anthropic actions.

Considering the $\mathrm{OM}$ increase due to anthropic origins, it can also be associated with metal contamination levels increase (Belo et al., 2010) and that organic sediments, such as those found in this study, allow the complexation of metals (Jackson, 1978; Pompêo et al., 2013), there is a doubly critical scenario involving the reservoir in question. For this reason, it is necessary to constantly monitor the quality of the sediment, especially OM levels. Thus, strategic decisions can be taken aiming to the protection of water resources and the quality of water for human consumption and protection of aquatic communities.

\subsection{Particle size analysis}

The granulometric analysis demonstrates low sand percentages in all sampling stations. The higher presence of fine sand was observed at the reservoir's entrance zone, stations S7, S8 and S9 (Figure 4). According to Thornton et al. (1990), the presence

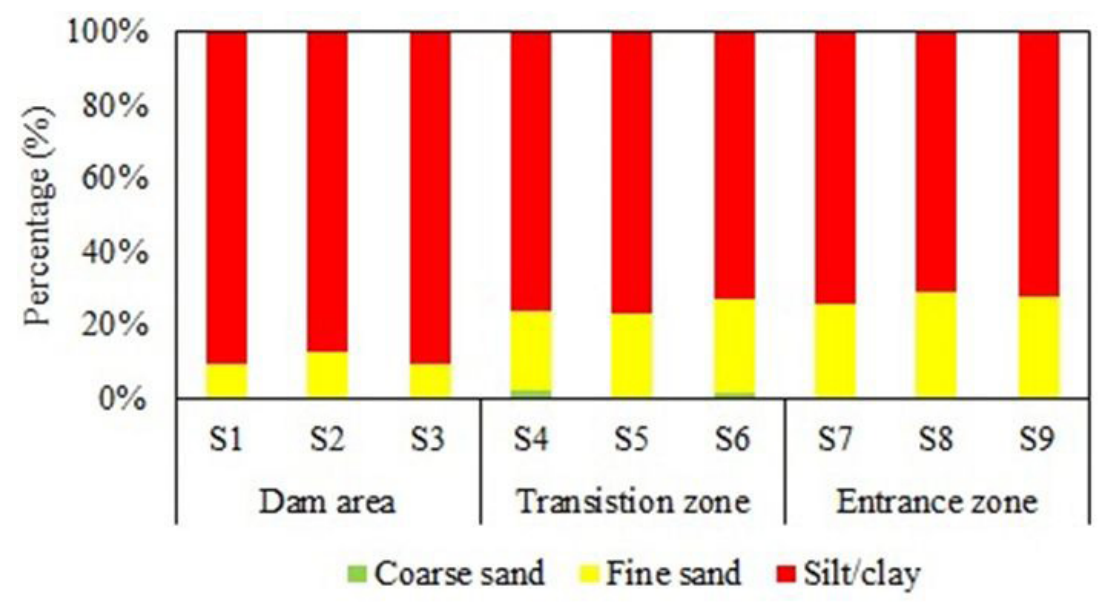

Figure 4. Particle size (\%) composition of surface sediments at each sampling station (S). The graph shows the percentage of coarse sand, fine sand and silt/clay at each sampling station, divided into dam area, transition zone and reservoir's entrance zone. 
of sand, in greater proportions, in the entrance zone is an intrinsic characteristic to the reservoirs, due to the greater water flow. However, one factor that must be considered is the sand extracting process at the head of the reservoir, which is historically practiced in the region of Sorocaba and, even today, contributes to silting and influences negatively the local ichthyofauna (Smith et al., 2019). It is believed that this process can contribute to the alteration of some granulometric characteristics of the reservoir (Silva, 2012).

Coarse sand was detected only at stations S4 and S6, making up 6\% and 4\%, respectively. These stations are close to the reservoir's tributaries. Pompêo et al. (2013) found in the Guarapiranga reservoir, in the Alto Tietê region, a predominance of silt/clay fractions, however, coarse sand was not found in any of the sampled stations. Regarding the dam area, it was evident the presence in a smaller amount of sand, due to the hydrodynamics of the reservoir, found also by Frascareli et al. (2018). The water velocity when entering the reservoir is decreased, therefore, it creates conditions for sediment deposition. The heavier particles, such as boulders and coarse sands, are the first to settle, while the finer sediment enters the reservoir (ANEEL, 2000). The main material found in the dam was silt/clay composing up to $92 \%$.

Szarek-Gwiazda \& Sadowska (2010) after studying a sub-mountainous reservoir, found that the presence of OM is correlated with the grain size, the higher the OM content, the smaller the grains of this sediment are. This was observed in a similar way in the samples from Itupararanga, where the $\mathrm{OM}$ ratio and the granulometric characteristics of the analyzed sediment were the similar, high OM indices and predominantly clay grains.

When plotting the mean and standard deviation values in the distribution of the granulometric samples, it was found that the means were low. The coefficient of variation for coarse sand was very high (173\%), compared to fine sand (11\%) and silt/ clay $(8 \%)$, due to the presence of larger grains in only two stations of the nine sampled, the analysis of variance showed that there was no significance with other parameters $(p>0.05)$.

Significant Pearson's correlations were found ( $p=0.0001)$ between the levels of silt/clay and water depth $(r=0.96)$ and fine sand $(r=-0.97)$. The presence of larger particles in the upper part of the reservoir, as expected, suggests that fluvial discharges constantly occur in the reservoir.

\subsection{Water column depth}

Water column depth is one of the morphometric parameters of greatest limnological relevance, with regard to several biological and chemical aspects related to the reservoirs, such as susceptibility to wind action, thermal amplitude, biological productivity, solar radiation range, eutrophication, and stratification conditions (Cole, 2015). The amount of OM, as well as the granulometric characteristics, can also be influenced by this parameter, so the discussion about the performance of this factor is of great relevance. In this study, sediment collection was carried out at points where depth varied from 5 to $18 \mathrm{~m}$, as shown in Table 1 .

In Figure 5, the spatial distribution of the water column depth can be seen. In the present study, the highest percentages of OM were found in the samples referring to the reservoir entry station (S3), the shallowest region. The correlation between depth and OM was negative $(\mathrm{r}=-0.89)$ and significant $(\mathrm{p}=0.001)$. Frascareli et al. (2018) observed the opposite phenomenon, relating higher levels of OM to deeper regions. This divergence can be attributed to seasonal and spatial variations, which have a strong influence on reservoir rates (Andreoli \& Carneiro, 2005). In addition, factors such as the use of the surrounding soil and sewers discharges can change the reservoir's characteristics and, consequently the sediments. Significant linear correlations were observed between the depth and the silt and clay contents $(r=0.96)$ and fine sand $(r=-0.97)$. This relationship indicates that the fine sediment is more easily deposited in the deepest and closest area to the dam.

\subsection{Metal complexation}

The influence exerted by the granulometric characteristics of the sediment are several, affecting mainly the sedimentation process and some chemical parameters. The sedimentation speed, for example, varies according to the material that makes up each sediment, the smaller the grain, the lower the sediment decanting speed and the greater the amount of suspended material (McLusky, 1989). In fine sediments there is a greater volume of interstitial water, that is, greater water retention and higher levels of $\mathrm{OM}$ and dissolved oxygen are also observed. In addition, metals are preferably associated with finer sediment fractions, such as silt and clay (Föstner \& Salomons, 1980).

In order to investigate the potential of metal complexation in sediment samples from Itupararanga, $\mathrm{Cr}, \mathrm{Cu}, \mathrm{Ni}, \mathrm{Mn}, \mathrm{Pb}$, and $\mathrm{Zn}$ were 


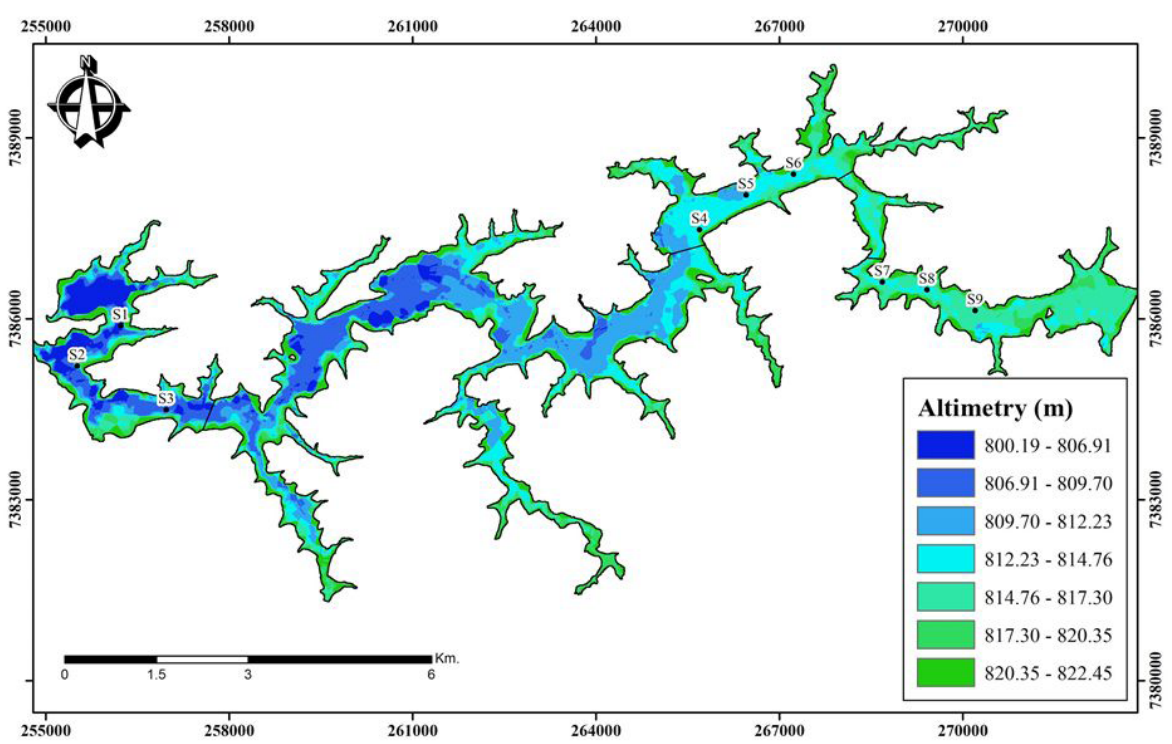

Figure 5. Altimetric map of Itupararanga reservoir, maximum depth: blue zones (800.19-806.91). The map shows the Itupararanga reservoir's depth, in meters, in order to evaluate the relationship between the granulometric fractions and the depth at which the sampling collections were performed.

Table 2. Spatial variation of concentration of Copper $(\mathrm{Cu})$, Chromium $(\mathrm{Cr})$, Nickel $(\mathrm{Ni})$, Lead $(\mathrm{Pb})$ and $\mathrm{Zinc}(\mathrm{Zn})$ $\left(\mathrm{mg} \mathrm{kg}^{-1}\right)$ in sediments of the Itupararanga Reservoir (Sáo Paulo State, Brazil), standard deviation, coefficient of variation and regional reference values (RRV) (Cardoso-Silva et al., 2021).

\begin{tabular}{|c|c|c|c|c|c|c|}
\hline \multirow{2}{*}{ Sampling stations } & $\mathrm{Cr}$ & $\mathrm{Cu}$ & $\mathrm{Ni}$ & $\mathrm{Mn}$ & $\mathbf{P b}$ & $\mathrm{Zn}$ \\
\hline & \multicolumn{6}{|c|}{$\mathrm{mg} \mathrm{kg}^{-1}$} \\
\hline S1 & 45.71 & 32.35 & 14.18 & 191.89 & 26.06 & 67.57 \\
\hline S2 & 46.24 & 30.56 & 13.70 & 260.08 & 24.78 & 59.34 \\
\hline S3 & 54.19 & 37.53 & 12.90 & 208.81 & 18.34 & 51.05 \\
\hline S4 & 48.46 & 29.51 & 17.51 & 139.96 & 21.20 & 53.32 \\
\hline S5 & 48.61 & 28.06 & 18.91 & 151.16 & 23.29 & 57.15 \\
\hline S6 & 44.52 & 24.19 & 17.76 & 139.48 & 22.45 & 56.01 \\
\hline S7 & 48.60 & 22.22 & 20.51 & 164.80 & 26.63 & 63.15 \\
\hline S8 & 44.63 & 20.76 & 18.88 & 179.91 & 27.14 & 61.80 \\
\hline s9 & 44.65 & 20.32 & 19.37 & 146.99 & 24.94 & 62.00 \\
\hline Standard deviation & 3.12 & 5.84 & 2.77 & 39.73 & 2.85 & 5.19 \\
\hline Minimum & 44.52 & 20.32 & 12.90 & 139.48 & 18.34 & 51.05 \\
\hline Maximum & 54.19 & 37.53 & 20.51 & 260.08 & 27.14 & 67.57 \\
\hline Mean concentration & 47.29 & 27.28 & 17.08 & 175.90 & 23.87 & 59.04 \\
\hline Coefficient of variation & 6.60 & 21.41 & 16.22 & 22.59 & 11.94 & 8.79 \\
\hline Reference value & 32.7 & 19.20 & 8.70 & 583.90 & 25.80 & 40.80 \\
\hline
\end{tabular}

quantified. The concentrations are shown in Table 2 together with the respective, standard deviation, minimum, maximum values and mean concentrations (Cardoso-Silva et al., 2021).

$\mathrm{Cr}$ values varied between $44.52 \mathrm{mg} \mathrm{kg}^{-1}$ and $54.19 \mathrm{mg} \mathrm{kg}^{-1}$, without major changes between the stations, with a variation coefficient of $6.60 \mathrm{mg}$ $\mathrm{kg}^{-1}$. The Cr concentration showed low variations, however, it was constant throughout the reservoir. In addition, the values found were higher than the baseline values $\left(32.7 \mathrm{mg} \mathrm{kg}^{-1}\right)$ established by Cardoso-Silva et al. (2021). The continuous presence of $\mathrm{Cr}$ may be associated with specific sources of agriculture that exist around the reservoir (Frascareli et al., 2015), then it ends up being transported throughout the water body. Fertilizers 
are one of the main sources of metals such as: $\mathrm{Cd}$, $\mathrm{Cr}, \mathrm{Mo}, \mathrm{Pb}, \mathrm{U}, \mathrm{V}$, and Zn (Alloway, 1995).

The $\mathrm{Cu}$ showed higher values at the entrance to the reservoir $\left(32.25 \mathrm{mg} \mathrm{kg}^{-1}, 30.56 \mathrm{mg} \mathrm{kg}^{-1}\right.$ and $37.53 \mathrm{mg} \mathrm{kg}^{-1}$ ), with its concentration reduced from the central area to the reservoir inlet. This is due to the fact that $\mathrm{Cu}$ has a strong affinity with $\mathrm{Mn}$, which also had high concentrations in the dam area (U.S. EPA, 1992).

$\mathrm{Ni}$ showed a maximum value of $20.51 \mathrm{mg} \mathrm{kg}^{-1}$ and a minimum of $12.90 \mathrm{mg} \mathrm{kg}^{-1}$. Among all metals, $\mathrm{Ni}$ had the lowest concentrations. Frascareli et al. (2018) found mean values of $7.82 \pm 0.95 \mathrm{mg}$ $\mathrm{Ni} \mathrm{kg}{ }^{-1}$ along the reservoir and Cardoso-Silva et al. (2021) established the reference value of $8.7 \mathrm{mg}$ $\mathrm{Ni} \mathrm{kg}{ }^{-1}$ at the dam area of the reservoir. Both authors did not find $\mathrm{Ni}$ enrichment spatially or temporally, respectively. Both Frascareli et al. (2018) and Cardoso-Silva et al. (2021), carried out the samplings in 2015 and applied the same methods of the present research. It is possible that $\mathrm{Ni}$ inputs have increased since them through agricultural activities around the reservoir. $\mathrm{Ni}$ is a micronutrient used in crops to increase system productivity (Fageria et al., 2002). In some sampling stations $\mathrm{Ni}$ toxicity is uncertain to occur $(18<\mathrm{Ni}<36)$ according to empirical sediment quality guideline values, ISQG (interim sediment quality guideline) and PEL (probable effect level) (CCME, 2001). This data suggests increased degradation in the region. Therefore, is important a frequent monitoring, including the sediments with the control of land use and occupation in the watershed.

The Mn presented the highest levels among all the analyzed metals, oscillating between $260.08 \mathrm{mg} \mathrm{kg}^{-1}$ and $139.48 \mathrm{mg} \mathrm{kg}^{-1}$, with an average concentration of $175.90 \mathrm{mg} \mathrm{kg}^{-1}$, however these values are according to regional references (583.9 $\mathrm{mg} \mathrm{Mn} \mathrm{kg}^{-1}$ ) (Cardoso-Silva et al. 2021). The highest values of $\mathrm{Mn}$ were found in the reservoir upper part and can be associated to the associated with the input of effluents from urbanized areas. Manganese is commonly found in municipal wastewater; however, it is normally present at concentrations that do not pose any environmental risks (Vymazal \& Švehla, 2013).

The $\mathrm{Pb}$ and $\mathrm{Zn}$ showed fluctuations in concentrations throughout the reservoir, ranging between $18.34 \mathrm{mg} \mathrm{kg}^{-1}$ and $27.14 \mathrm{mg} \mathrm{kg}^{-1}$ and $51.05 \mathrm{mg} \mathrm{kg}^{-1}$ and $67.57 \mathrm{mg} \mathrm{kg}^{-1}$, respectively. Although there are no signs of $\mathrm{Pb}$ contamination, there was an increase in its contents in the upstream direction. The same pattern was observed by
Rosa et al. (2015). This pattern may be linked to the higher proportion of smaller particles in the dam area. The $\mathrm{Zn}$ showed higher levels at the entrance of the reservoir. We considered that the increase in $\mathrm{Zn}$ in this region relies on the fact that Una River transports effluents from the city of Ibiúna, which has a plastic packaging industry.

Through the principal component analysis (PCA) (Figure 6), it was possible to observe a clear separation between the three compartments sampled in the Itupararanga reservoir.

Axis 1 explained $64.28 \%$ of the variability of the data and together with axis 2 , in total $88.40 \%$. Axis 1 ordination score was mainly influenced by the contents of OM (0.97), $\mathrm{Ni}(0.94)$ and fine/ coarse sand (0.91), influencing the stations of the upper part and the intermediate zone of the reservoir. Still on axis 1, the levels of $\mathrm{Cu}(-0.96)$, silt/clay (-0.89) and Mn (-0.62), influenced the positioning of the stations located in the vicinity of the dam area (S1-S3). Axis 2 ordination scores was negatively influenced by the contents of $\mathrm{Cr}(-0.51)$ and positively by the contents of $\mathrm{Zn}(0.85)$ and $\mathrm{Pb}$ (0.74), influencing the positioning of the samples at the stations of the reservoir transition area.

The highest levels of fine/coarse sand and OM in the transition zone may be from anthropic origin, due to the use of fertilizers by agricultural areas (Cunha et al., 2019; Frascareli et al., 2015; Pedrazzi et al., 2014). The increase of $\mathrm{Mn}$ in the upstream direction shows that the presence of other substances, such as the high percentages of $\mathrm{OM}$, may have influenced the lower concentration of the metal at the entrance of the reservoir. The lower levels of metals at this station may be related to the lower percentage of granulation below $63 \mu \mathrm{m}$. Mn is a metal that indicates erosive processes (Wang et al., 2012). The increase in Mn levels towards the dam could be associated with an increase in erosive processes. According to Frascareli et al. (2015), land uses in the area of the dam and transition are predominantly agricultural and urban, these activities intensify the erosion process. Frascareli et al. (2015) described the dam area for agricultural purposes. Such activities could increase erosive processes which are linked to higher levels of Mn.

The Alto Sorocaba basin has a drainage network with dendritic morphometry (Ross \& Moroz, 1997), favoring the absence of fine sand at the entrance to the reservoir, as it is an area with less nutrient input, flow rate and residence time, they can also influence the dynamics in these 


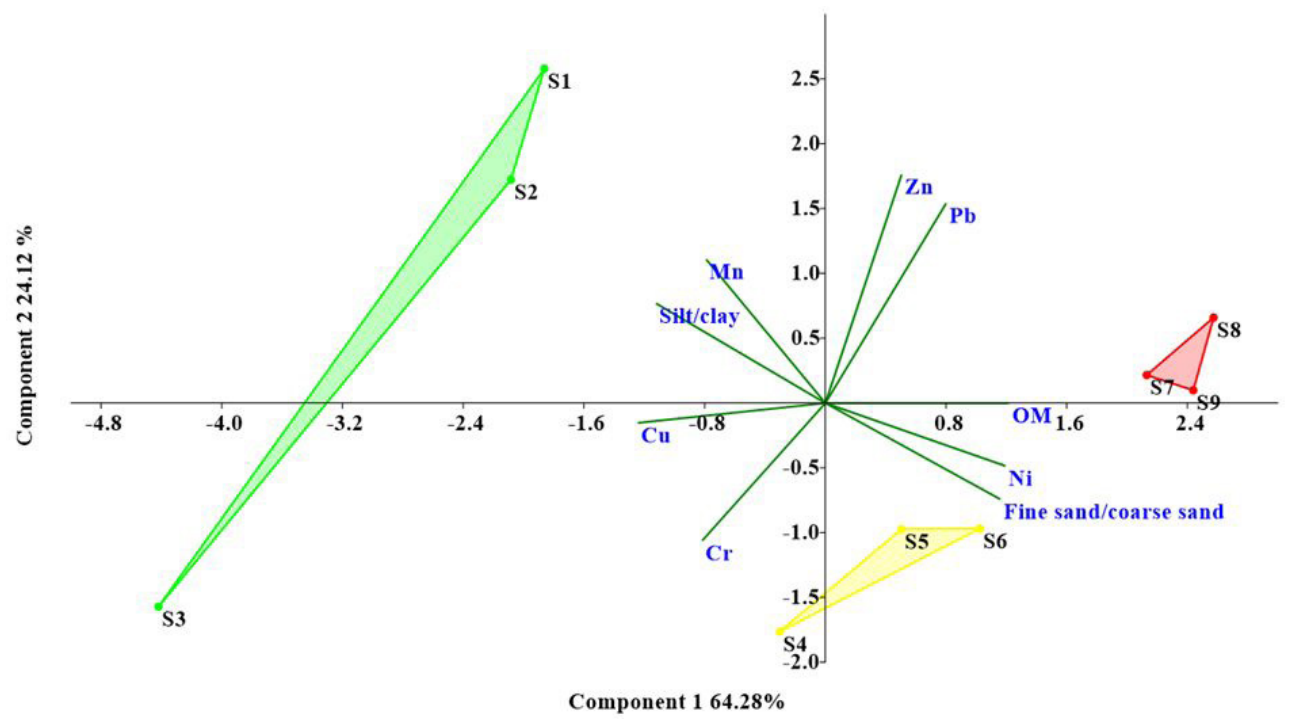

Figure 6. Principal component analysis (PCA) of metal samples and percentage distribution of organic matter and granulometry. The PCA shows the separation among the sampling collection stations $(S)$, through the components 1 and 2, correlating the $\mathrm{OM}$ and the granulometric fractions with the metal concentrations present in the reservoir.

environments (Straškraba et al., 1993). While the high fractions of coarse sand and silt/clay observed in the same compartment contributed to the high concentrations of $\mathrm{Mn}$ in this zone, this metal being strongly complexed to humic compounds and the presence of finer fractions, which provides greater interaction with different ions and diverse molecules due to a larger surface area (Bevilacqua et al., 2009). Cunha et al. (2019) observed that there is a direct relationship between the silt and the increase in soil erosion around a reservoir dam.

The highest concentrations of OM and high fractions of fine/coarse sand influenced the positioning of these variables on axis 1 . Thus, axis 1 can be characterized by the action of anthropic activities, the highest levels of OM can be a consequence of high concentrations of nutrients previously registered at the entrance to the reservoir as a result of the release of illegal effluents from irregular urbanization around the source. On the other hand, in axis 2, the variables that most influenced this component were the contents of $\mathrm{Pb}$ and $\mathrm{Zn}$. The trace metals are attracted by the high presence of clays and organic components present in the sediment, contributing to high concentrations of $\mathrm{Pb}$ and $\mathrm{Zn}$. In addition to the anthropic influence, aquatic environments have the ability to make metals more bioavailable naturally, due to the adsorption of particulate material and the natural presence of ions (Melo et al., 2012). As there is no evidence of contamination for these metals in the Itupararanga reservoir, the association of these metals in this region reflects the natural geochemical composition.

Spatially, the metals showed low variability in concentrations, with no evident linear patterns along the reservoir's longitudinal gradient. The exceptions were $\mathrm{Cu}$ and $\mathrm{Mn}$, which presented a variation coefficient of $21.41 \%$ and $22.59 \%$, respectively. Magalhães et al. (2016) observed that contributions from these metals are supposedly linked to agricultural and mining activities.

The complexation of metals occurs more quickly when in contact with the organic fraction (Sparks, 2003). However, it is necessary to consider that the availability of the metals, the granulometric fraction of the sediment and the chemical reactions that involve the complexation also suffer with the interference of natural dynamic processes of the ecosystem. From this standpoint, the reservoir's region that has the greatest potential for metal complexation refers to the stations located near the dam, where the depth together with the silt/clay fractions can provide a favorable environment for the bonding and complexation process.

\section{Conclusion}

This work addresses the indispensability of the study of physical and chemical parameters of reservoir sediments, since sediments play a clue role as an indicator of water quality, due to their 
direct relationship and capacity for pollutant bioaccumulation.

Based on the different analyzes carried out on the Itupararanga Reservoir sediment, it can be concluded that the sediment is predominantly organic and that there is heterogeneity in terms of OM, granulometric fractions and metal concentration. The three zones of the reservoir are quite distinct from each other, each presenting a specific relationship with a certain granulometric fraction of the sediment and with certain metals. The dam region had the highest levels of metals, possibly from agricultural activities, such as $\mathrm{Cu}$ and Mn.

The satellite imagery allowed to delimitate and classify the land use within the Itupararanga EPA, indicating high impact to the natural attributes, which influence directly to the reservoir's quality. Therefore, it is essential to create and apply more efficient management tools among the municipalities in the EPA to conserve the biodiversity in the region. This study demonstrates the need to elaborate and apply strategies to promote and secure the EPAs and reservoirs inter-relationship and multifunctionality.

\section{Acknowledgements}

This work was carried out with the support of the Coordenação de Aperfeiçoamento de Pessoal de Nível Superior - Brazil (CAPES) Financing Code 001; Fundaçáo de Amparo à Pesquisa do Estado de São Paulo (FAPESP) (processes 2016/24528-2, 2019/10845-4); the Conselho Nacional de Desenvolvimento Científico e Tecnológico (CNPq) (processes 400305/2016-0); and the Programa de Estudantes-Convênio de Pós-Graduação (PEC-PG), from CAPES/CNPq (process 190216/2017-4).

\section{References}

ABELL, R., VIGERSTOL, K., HIGGINS, J., KANG, S., KARRES, N., LEHNER, B., SRIDHAR, A. and CHAPIN, E. Freshwater biodiversity conservation through source water protection: quantifying the potential and addressing the challenges. Aquatic Conservation, 2019, 29(7), 1022-1038. http://dx.doi. org/10.1002/aqc.3091.

ABREU, M.C. and TONELLO, K.C. Avaliação dos parâmetros hidrometeorológicos na Bacia do Rio Sorocaba/SP. Revista Brasileira de Meteorologia, 2017, 32(1), 99-109. http://dx.doi.org/10.1590/0102778632120150164.

AGÊNCIA NACIONAL DAS ÁGUAS - ANA. Guia nacional de coleta e preservação de amostras: água, sedimento, comunidades aquáticas e efluentes líquidos [online]. São Paulo: CETESB; Brasília: ANA, 2011 [viewed 5 May 2021]. Available from: https:// arquivos.ana.gov.br/institucional/sge/CEDOC/ Catalogo/2012/GuiaNacionalDeColeta.pdf

AGÊNCIA NACIONAL DE ENERGIA ELÉTRICA - ANEEL. Guia de avaliação de assoreamento de reservatórios. Brasília: ANEEL, 2000 [viewed 5 May 2021]. Available from: http://www.aneel. gov.br/documents/656835/14876406/2000_ GuiaAvaliacaoAssoreamentoReservatorios. pdf/68c44953-f696-5925-573a-b7b3207db875

ALLOWAY, B.J. Heavy metals in soils. London: Blackie Academic \& Professional, 1995. http://dx.doi. org/10.1007/978-94-011-1344-1.

ALMEIDA, V.P., CARVALHO, R.B. and CATHARINO, E.L.M. Flora. In: S.E. BEU, A.C. SANTOS and S.P. CASALI, eds. Biodiversidade na APA de Itupararanga: condiçōes atuais e perspectivas futuras. São Paulo: SMA/ FF/UFSCar/CCR/Via Oeste, 2011, pp. 72-77.

AN, S., XIE, X. and MA, Y. Evaluation of water quality using principal component analysis. Nature Environment and Pollution Technology, 2015, 14(4), 855-858.

ANDREOLI, C.V. and CARNEIRO, C. Integrada de mananciais de abastecimento eutrofizados. Curitiba: SANEPAR, 2005.

ATIQUE, U. and AN, K.G. Landscape heterogeneity impacts water chemistry, nutrient regime, organic matter and chlorophyll dynamics in agricultural reservoirs. Ecological Indicators, 2020, 110, 105813. https://doi.org/10.1016/j.ecolind.2019.105813.

BELO, A., QUINÁIA, S.P. and PLETSCH, A.L. Avaliação da contaminação de metais em sedimentos superficiais das Praias do Lago de Itaipu. Química Nova, 2010, 33(3), 613-617. http://dx.doi. org/10.1590/S0100-40422010000300024.

BERNARDI, I., SILVA, L.R., FALCO, P.B., PIRES, J.S.R. and DOS SANTOS, A.C.A. Análise comparativa das ferramentas de gestáo: plano de manejo da APA Itupararanga e os Planos Diretores Municipais. Sociedade \& Natureza, 2020, 32, 7591. Sociedade \& Natureza, 2020, 32, 75-91. http:// dx.doi.org/10.14393/SN-v32-2020-36541.

BEU, S.E., MISATO, M.T. and HAHN, C.M. APA Itupararanga. In: S.E. BEU, A.C.A. SANTOS and S. CASALI, eds. Biodiversidade na APA Itupararanga: condiçōes atuais e perspectivas futuras. São Paulo: SMA/ FF/UFSCar/CCR/Via Oeste, 2011, pp. 33-56.

BEVILACQUA, J.E., SILVA, I.S., LICHTIG, J. and MASINI, J.C. Extração seletiva de metais pesados em sedimentos de fundo do Rio Tietê, São Paulo. Química Nova, 2009, 32(1), 26-33. http://dx.doi. org/10.1590/S0100-40422009000100005.

BING, H., WU, Y., NAHM, W.H. and LIU, E. Accumulation of heavy metals in the lacustrine sediment of Longgan Lake, middle reaches of Yangtze 
River, China. Environmental Earth Sciences, 2013, 69, 2679-2689.

CANADIAN COUNCIL OF MINISTERS OF THE ENVIRONMENT - CCME. Protocol for the derivation of canadian sediment quality guidelines for the protection of aquatic life. Ottawa, Canada: CCME, 2001, pp. 35. Prepared by the technical secretariat of the CCME task group on water quality guidelines. Retrieved from https://www.pla.co.uk/Environment/ Canadian-Sediment-Quality-Guidelines-for-theProtection-of-Aquatic-Life

CARDOSO-SILVA, S., OLIVEIRA SOARES SILVA MIZAEL, J., FRASCARELI, D., ALVES DE LIMA FERREIRA, P., HENRIQUE ROSA, A., VICENTE, E., CÉSAR LOPES FIGUEIRA, R., L. M. POMPEOO, M. and MOSCHINI-CARLOS, V. Paleolimnological evidence of environmental changes in seven subtropical reservoirs based on metals, nutrients, and sedimentation rates. Catena, 2021, 206, 105432. http://dx.doi.org/10.1016/j. catena.2021.105432.

CARMO, D.L. and SILVA, C.A. Métodos de quantificação de carbono e matéria orgânica em resíduos orgânicos. Revista Brasileira de Ciência do Solo, 2012, 36(4), 1211-1220. http://dx.doi. org/10.1590/S0100-06832012000400015.

COLE, G.A. Textbook of limnology. Illinois, Waveland Press: Prospect Heights, 2015.

COMPANHIA AMBIENTAL DO ESTADO DE SÃO, PAULO - CETESB. Qualidade das Águas Interiores no Estado de São Paulo. São Paulo: CETESB, 2019. Report no. 2018 [viewed 5 May 2021]. Available from: https://cetesb.sp.gov.br/aguas-interiores/ wp-content/uploads/sites/12/2019/10/Relatóriode-Qualidade-das-Águas-Interiores-no-Estado-deSP-2018.pdf

CONSALTER, B.G., MIRANDA, D.M., SOUZA, J.S., FERRAREZI, A.D.M., FERRAREZI, J.G. and GASQUES, L.S., Avaliação da contaminação por cobre e chumbo do lago Aratimbó - Umuarama - PR. Arquivos de Ciências da Saúde, 2019, 23(2), 107-112. http://dx.doi.org/10.25110/arqsaude. v23i2.2019.6871.

CUNHA, B.G., MAGALHÃES-JUNIOR, E.B. and PEDROTTI, A. Erodibilidade dos solos do entorno do reservatório da barragem Jaime Umbelino de Souza, São Cristovão, Sergipe. Brazilian Journal of Development, 2019, 5(7), 10196-10205. http:// dx.doi.org/10.34117/bjdv5n7-178.

DA PAZ SCHILLER, A., FERRONATO, M.C., SCHWANTES, D., GONÇALVES JUNIOR, A. C., BARILLI, D. J. and MANFRIN, J. Influence of hydrological flows from tropical watersheds on the dynamics of $\mathrm{Cu}$ and $\mathrm{Zn}$ in sediments. Environmental Monitoring and Assessment, 2019, 191, 86. https:// doi.org/10.1007/s10661-019-7193-x.
DE CASTRO, P.H.M., PEREIRA, A.C.F. and BARROS, M.V.F. Modelagem amostral para o monitoramento de componentes opticamente ativos No Rio Tibagi/Pr, Utilizando Imagens Landsat 8/ Oli. Revista Brasileira de Cartografia, 2017, 7(69), 1231-1246.

DE MELO GURGEL, P., NAVONI, J.A., DE MORAIS FERREIRA, D. and DO AMARAL, V.S. Ecotoxicological water assessment of an estuarine river from the Brazilian Northeast, potentially affected by industrial wastewater discharge. The Science of the Total Environment, 2016, 572, 324-332. http://dx.doi.org/10.1016/j.scitotenv.2016.08.002. PMid:27505265.

ESTEVES, F.A. Fundamentos da limnologia. Rio de Janeiro: Interciências, 2011.

FAGERIA, N.K., BALIGAR, V.C. and CLARK, R.B. Micronutrients in Crop Production. Advances in Agronomy, 2002, 77, 185-268. http://dx.doi. org/10.1016/S0065-2113(02)77015-6.

FÖSTNER, U. and SALOMONS, W. Trace metals analysis on polluted sediments. Part I: Assessments of sources and intensities. Environmental Science \& Technology Letters, 1980, 1(11), 495-505.

FRASCARELI, D., BEGHELLI, F.G., DA SILVA, S.C. and CARLOS, V.M. Heterogeneidade espacial e temporal de variáveis limnológicas no Reservatório de Itupararanga Associadas com o Uso do Solo na Bacia do Alto Sorocaba-SP. Revista Ambiente \& Água, 2015, 10(4), 770-781. http://dx.doi.org/10.4136/ ambi-agua. 1715 .

FRASCARELI, D., CARDOSO-SILVA, S., DE OLIVEIRA SOARES-SILVA MIZAEL, J., ROSA, A.H., POMPÊO, M.L.M., LÓPEZ-DOVAL, J.C. and MOSCHINI-CARLOS, V., Spatial distribution, bioavailability, and toxicity of metals in surface sediments of tropical reservoirs, Brazil. Environmental Monitoring and Assessment, 2018, 190(4), 199. http://dx.doi.org/10.1007/s10661-018-6515-8. PMid:29520500.

HAMMER, Ø., DAT, H. and RYAN, P.D. PAST: paleontological statistics software package for education and data analysis. Palaeontologia Electronica, 2001, 4(1), 1-9.

HEIRI, O., LOTTER, A.F. and LEMCKE, G. Loss on ignition as a method for estimating organic and carbonate content in sediments: reproducibility and comparability of results. Journal of Paleolimnology, 2001, 25(1), 101-110. http:// dx.doi.org/10.1023/A:1008119611481.

HENRY, R. Estrutura especial e temporal do ambiente fisico e químico a análise de alguns processos ecológicos na Represa de Jurumirim (Rio Paranapanema, SP) e na Sua Bacia Hidrográfica [Tese]. Botucatu: Universidade Estadual Paulista "Júlio de Mesquita Filho", 1990. 
JACKSON, T.A. The biogeochemistry of heavy metals in polluted lakes and streams at Flin Flon, Canada, and a proposed method for limiting heavy-metal pollution of natural waters. Environmental Geology, 1978, 2(3), 173-189. http://dx.doi.org/10.1007/BF02430671.

LEAL, P.R., MOSCHINI-CARLOS, V., LÓPEZDOVAL, J.C., CINTRA, J.P., YAMAMOTO, J.K., BITENCOURT, M.D., SANTOS, R.F., ABREU, G.C. and POMPÊO, M.L.M. Impact of copper sulfate application at an urban brazilian reservoir: a geostatistical and ecotoxicological approach. The Science of the Total Environment, 2018, 618, 621-634. http://dx.doi.org/10.1016/j.scitotenv.2017.07.095. PMid:29054669.

LIU, Q., TIAN, Y., LIU, Y., YU, M., HOU, Z., HE, K., XU, H., CUI, B. and JIANG, Y. Relationship between dissolved organic matter and phytoplankton community dynamics in a human-impacted subtropical river. Journal of Cleaner Production, 2021, 289, 125144. http://dx.doi.org/10.1016/j. jclepro.2020.125144.

MAGALHÃES, G.C., FANTIN-CRUZ, I., ZEILHOFER, P. and DORES, E.F.G.C. Metais potencialmente tóxicos em rios a montante do Pantanal Norte. Revista Ambiente \& Água, 2016, 11(4), 833-850. http://dx.doi.org/10.4136/ambiagua. 1827.

MCLUSKY, D.S. The estuarine ecosystem. New York: Chapman \& Hall, Glasgow, 1989.

MELO, D.S., GONTIJO, E.S.J., FRASCARELI, D., SIMONETTI, V.C., MACHADO, L.S., BARTH, J.A.C., MOSCHINI-CARLOS, V., POMPÊO, M.L., ROSA, H.A. and FRIESE, K. Selforganizing maps for evaluation of biogeochemical processes and temporal variations in water quality of subtropical reservoirs. Water Resources Research, 2019, 55(12), 10268-10281. http://dx.doi. org/10.1029/2019WR025991.

MELO, V. F., ANDRADE, M., BATISTA, A.H., FAVARETTO, N., GRASSI, M.T. and CAMPOS, M.S. Chumbo e zinco em águas e sedimentos de área de mineração e metalurgia de metais. Química Nova, 2012, 35(1), 22-29.

MIZAEL, J.O.S.S., CARDOSO-SILVA, S., FRASCARELI, D., POMPÊO, M.L.M. and MOSCHINI-CARLOS, V. Ecosystem history of a tropical reservoir revealed by metals, nutrients and photosynthetic pigments preserved in sediments. Catena, 2020, 184, 104242. http://dx.doi. org/10.1016/j.catena.2019.104242.

PAVLOVIĆ, P., MITROVIĆ, M., ĐORĐEVIĆ, D., SAKAN, S., SLOBODNIK, J., LIŠKA, I., CSANYI, B., JARIĆ, S., KOSTIĆ, O., PAVLOVIĆ, D., MARINKOVIĆ, N., TUBIĆ, B. and PAUNOVIĆ, $\mathrm{M}$. Assessment of the contamination of riparian soil and vegetation by trace metals-A Danube River case study. The Science of the Total Environment,
2016, 540, 396-409. http://dx.doi.org/10.1016/j. scitotenv.2015.06.125. PMid:26184864.

PEDRAZZI, FJ.M., CONCEIÇÃO, F.T., SARDINHA, D.S., MOSCHINI-CARLOS, V. and POMPÊO, M.L.M. Avaliação da qualidade da água no reservatório de Itupararanga, bacia do alto Sorocaba (SP). Geociências, 2014, 33(1), 26-38.

PEDRAZZI, FJ.M., CONCEIÇÃO, F.T., SARDINHA, D.S., MOSCHINI-CARLOS, V. and POMPÊO, M. Spatial and Temporal quality of water in the Itupararanga Reservoir, Alto Sorocaba Basin (SP), Brazil. Journal of Water Resource and Protection, 2012, 5(1), 64-71. http://dx.doi.org/10.4236/ jwarp.2013.51008.

PÉREZ, M.A.M., RIZO, O.D., ACOSTA, H.G., SANTOS, O.A.A. and SÁNCHEZ-PÉREZ, J.M. Relationship between micro-granulometric profile and chemical sediment composition in mampostón sub-watershed, Mayabeque, Cuba. Journal of South American Earth Sciences, 2020, 101, 102538.

POMPÊO, M.L.M., PADIAL, P.R., MARIANI, C.F., CARDOSO-SILVA, S., MOSCHINI-CARLOS, V., DA SILVA, D.C.V.R., PAIVA, T.C.B. and BRANDIMARTE, A.L., Biodisponibilidade de metais no sedimento de um Reservatório Tropical Urbano (Reservatório Guarapiranga - São Paulo (SP), Brasil): há toxicidade potencial e heterogeneidade espacial? Geochimica Brasiliensis, 2013, 27(2), 104119.

PROSHAD, R., KORMOKER, T., MURSHEED, N., MONIRUL ISLAM, M., BHUYAN, M.I., SAZEDUL ISLAM, M. and MITHU, T.N. Heavy metal toxicity in agricultural soil due to rapid industrialization in Bangladesh: a review. International Journal of Advanced Geosciences, 2018, 6(1), 83-88. http://dx.doi.org/10.14419/ijag. v6i1.9174.

ROSA, A.H., SILVA, A.A.M.J., MELO, C. A., MOSCHINI-CARLOS, V., GUANDIQUE, M.E.G., FRACETO, L.F. and LOURENÇO, R.W. Diagnóstico ambiental e avaliação de uso e ocupação do solo visando a sustentabilidade da represa de itupararanga, importante área da bacia do Médio Tietê. In: M.L.M. POMPÊO, V. MOSCHINICARLOS, P.Y. NISHIMURA, S. CARDOSOSILVA \& J.C.L. DOVAL, eds. Ecologia de reservatórios $e$ interfaces. São Paulo: Institute of Biosciences, University de São Paulo, 2015, pp. 212-231.

ROSS, J.L.S. and MOROZ, I.C. Mapa geomorfológico do estado de São Paulo. Revista Do Departamento De Geografia, 1997, 10, 41-58.

SÁO PAULO. Lei n ${ }^{\circ} 11.579$, de 02 de Dezembro de 2003. Declara Área de Proteção Ambiental o Entorno da Represa de Itupararanga, Bem como Altera a Lei $\mathrm{n}^{\circ}$ 10.100, de 01 de Dezembro de 1998. Diário Oficial do Estado de São Paulo [online]. São Paulo, SP, 2003 [viewed 5 May 2021]. Available from: https:// 
www.al.sp.gov.br/repositorio/legislacao/lei/1998/ compilacao-lei-10100-01.12.1998.html

SCHAUMLÖFFEL, D. Nickel species: analysis and toxic effects. Journal of Trace Elements in Medicine and Biology, 2012, 26(1), 1-6. http://dx.doi. org/10.1016/j.jtemb.2012.01.002. PMid:22366237.

SHEPARD, D. A two-dimensional interpolation function for irregularly-spaced data. In: Proceedings of the ACM '68: Proceedings of the 1968 23rd ACM National Conference. New York: ACM, 1968. pp. $517-$ 524. http://dx.doi.org/10.1145/800186.810616.

SILVA, L.J., LOPES, L.G. and AMARAL, L.A. Qualidade da água de abastecimento Público do Município de Jaboticabal, SP. Engenharia Sanitária, 2016, 3(21), 615-622. http://dx.doi.org/10.1590/ S1413-41522016121151.

SILVA, S.A. Avaliação da concentração de micro $e$ macronutrientes do sedimento do reservatório Itupararanga/Sorocaba-SP [online] [Dissertação de mestrado em Ciências na área de Tecnologia Nuclear]. Sáo Paulo: Instituto de Pesquisas Energéticas e Nucleares, 2012 [viewed 5 May 2021]. Available from: http://pelicano.ipen.br/PosG30/TextoCompleto/ Sharlleny\%20Alves\%20Silva_M.pdf

SMITH, W.S., SILVA, F.L.D. and BIAGIONI, R.C. Desassoreamento de Rios: quando o poder público ignora as causas, a biodiversidade e a ciência. Ambiente \& Sociedade, 2019, 22, e00571. http:// dx.doi.org/10.1590/1809-4422asoc0057r1vu19l1ao.

SPARKS, D.L. Environmental soil chemistry. 2nd ed. Newark: Academic Press, 2003. http://dx.doi. org/10.1016/B978-012656446-4/50001-3.

STRAŠKRABA, M., TUNDISI, J.G. and DUNCAN, A. State of the art of reservoir limnology and water quality management. In: M. STRAŠKRABRA, J.G. TUNDISI and A. DUNCAN, eds. Comparative reservoir limnology and water quality management. USA: Kluwer Academic Publishers, 1993, pp. 213-288. http://dx.doi.org/10.1007/978-94-0171096-1_13.

SUGUIO, K. Introdução a sedimentologia. São Paulo: Edgard Blücher, 1973.

SZAREK-GWIAZDA, E. and SADOWSKA, I. Distribution of grain size and organic matter content in sediments of submontane dam reservoir. Environment Protection Engineering, 2010, 36(1), 113-124.

TANIWAKI, R.H., ROSA, A.H., CALIJURI, M.D.C. and CARLOS, V.M. Variação espacial do grau de trofia e da biomassa fitoplanctônica no reservatório de Itupararanga (São Paulo, Brasil). Holos Environment, 2011, 11(2), 171. http://dx.doi.org/10.14295/holos. v11i2.5632.
TANIWAKI, R.H., ROSA, A.H., DE LIMA, R., MARUYAMA, C.R., SECCHIN, L.F., DO CARMO CALIJURI, M. and MOSCHINICARLOS, V. A influência do uso e ocupação do solo na qualidade e genotoxicidade da água no Reservatório de Itupararanga, São Paulo, Brasil. Interciencia, 2013, 8(3), 164-170. https://orcid. org/0000-0002-2042-018X.

THORNTON, K.W., PAYNE, F.E. and KIMMEL, B.L. Reservoir limnology: ecological perspectives. New York: Wiley-Blackwell, 1990.

U.S. ENVIRONMENTAL PROTECTION AGENCY USEPA. Behavior of metal in soil (EPA/540/S-92/018). Washington: USEPA, 1992.

U.S. ENVIRONMENTAL PROTECTION AGENCY - USEPA. Methods for collection, storage and manipulation of sediments for chemical and toxicological analyses: technical manual (EPA 823-b-01-002). Washington: USEPA, 2001.

UNITED STATES GEOLOGICAL SURVEY - USGS. Landsat Missions. United States Geological Survey, 2021. Available from: https://www.usgs.gov/corescience-systems/nli/landsat.

VALENTE, R.O.A. Conservação dos ecossistemas terrestres. In: S.E. BEU, A.C.A. SANTOS and S. CASALI, eds. Biodiversidade na APA Itupararanga: condições atuais e perspectivas futuras. São Paulo: SMA/ FF/UFSCar/CCR/Via Oeste, 2011, pp. 57-64.

VON EYNATTEN, H., TOLOSANA-DELGADO, R., KARIUS, V., BACHMANN, K. and CARACCIOLO, L. Sediment generation in humid mediterranean setting: grain-size and source-rock control on sediment geochemistry and mineralogy (Sila Massif, Calabria). Sedimentary Geology, 2016, 336, 68-80. http://dx.doi.org/10.1016/j. sedgeo.2015.10.008.

VYMAZAL, J. and ŠVEHLA, J. Iron and manganese in sediments of constructed wetlands with horizontal subsurface flow treating municipal sewage. Ecological Engineering, 2013, 50, 69-75. http://dx.doi. org/10.1016/j.ecoleng.2012.04.027.

WANG, C., LIU, S., ZHAO, Q., DENG, L. and DONG, $S$. Spatial variation and contamination assessment of heavy metals in sediments in the Manwan Reservoir, Lancang River. Ecotoxicology and Environmental Safety, 2012, 82, 32-39. http://dx.doi.org/10.1016/j. ecoenv.2012.05.006. PMid:22664225.

Received: 05 May 2021 Accepted: 09 September 2021

Associate Editor: Carla Ferragut. 